\title{
Investigation of Validity, Reliability and Acceptability of the Turkish Version of the 15D Questionnaire Health-Related Quality of Life on the People with Visual Impairment
}

\author{
Görme Engelli Bireylerde 15D Sağlıkla İlgili Yaşam \\ Kalitesi Anketi Türkçe Formunun Geçerlik, Güvenirlik \\ ve Kabul Edilirliğinin Araştırılması
}

\section{Mintaze Kerem GÜNEL, ${ }^{a}$ Emine Handan TÜZÜN, \\ Esra AKi, ${ }^{a}$ Levent EKER, MDc}

aDepartment of Physical Therapy and Rehabilitation,

Hacettepe University,

Faculty of Health Sciences,

'Department of Physical Therapy and Rehabilitation,

Baskent University,

Faculty of Health Sciences,

'Mother and Child Health Care and

Family Planning General Directorate,

Ministry of Health, Ankara

Geliş Tarihi/Received: 02.09 .2008

Kabul Tarihi/Accepted: 14.02.2009

Yazışma Adresi/Correspondence: Mintaze Kerem GÜNEL

Hacettepe University,

Faculty of Health Sciences,

Department of Physical Therapy and

Rehabilitation, Ankara,

TÜRKIYE/TURKEY

mintaze@yahoo.com

\begin{abstract}
Objective: This study aims to establish the validity and reliability of the Turkish version of the 15D questionnaire in a population of visually-impaired subjects. Material and Methods: Fifty-seven people (mean age: $36.6 \pm 12.3$ years) who have a visual impairment and 63 sighted people (mean age: $54.4 \pm 11.6$ years) participated in this study. A background questionnaire, 15D questionnaire, the Family Affluence Scale (FAS), and the Beck Depression Inventory (BDI) were used. Results: Among socio-demographic variables studied, the age $(r=-0.41 ; 95 \%$ CI:- 0.61 to- $0.17 ; \mathrm{p}<$ $0.05)$, having an additional chronic health problem ( $\mathrm{r}=-0.46$; $95 \% \mathrm{CI}:-0.64$ to- 0.23$)$ and BDI score $(\mathrm{r}=-0.63$; $95 \%$ CI: -0.61 to- 0.17 ; $\mathrm{p}<0.05)$ were significantly correlated with $15 \mathrm{D}$ index score. Reliability was assessed for subjects who participated both in the first and second interviews $(\mathrm{N}=52)$. Cronbach's alpha for the 15D questionnaire was 0.75 at Time 1 and 0.78 at Time 2, which was obtained after removal of two dimensions (dimensions \# 6 and 7) from the index because of zero variance. ICC for the $15 \mathrm{D}$ index was 0.95 . Conclusion: It was concluded that the Turkish version of the generic 15D questionnaire was an acceptable, valid and reliable measure of health related quality of life for people with visually-impairment.
\end{abstract}

Key Words: Quality of health care; vision disorders

ÖZET Amaç: Bu çalışma 15D sağlıkla ilgili yaşam kalitesi anketi Türkçe formunun görme engelliler için geçerlik, güvenirlik ve kabul edilirliğini araştırmak amacıyla planlandı. Gereç ve Yöntemler: Yaş ortalaması $36.3 \pm 12.3$ yıl olan 57 görme engelli ile yaş ortalaması $54.4 \pm 11.6$ yıl olan görme engeli olmayan 63 kişi çalışmaya dahil edildi. 15D anketi, Aile Refah Anketi (ARA) ve Beck Depresyon Envanteri (BDE) kullanıldı. Bulgular: Çalışmadaki sosyo-demografik değişkenlerden yaş ( $\mathrm{r}=$ -0.41 ; $95 \%$ CI: -0.61 to -0.17 ; $p<0.05$ ), ek kronik bir sağlık sorununun olması ( $r=-0.46$; 95\% CI 0.64 to- 0.23 ) ve BDE puanı ( $\mathrm{r}=-0.63$; $95 \%$ CI:- 0.61 to- 0.17 ; $\mathrm{p}<0.05$ ) ile $15 \mathrm{D}$ anketi puanı arasında anlamlı bir ilişki vardı. Güvenirlik ilk ve son görüşmeye katılan 52 olgu üzerinde değerlendirildi. 15 D'nin iki alt ölçeği sıfır varyans değeri aldığı için, bu iki alt ölçek kullanılmadan bakılan (bölüm 6 ve 7) güvenirlikte, ilk doldurulan anket için Cronbach alpha değeri 0.75 bulunurken ve ikincisi için 0.78 olarak bulundu. 15D anketi için ICC değeri 0.95 olarak tespit edildi. Sonuç: Görme engelli bireylerde 15D sağlıkla ilgili yaşam kalitesi anketi Türkçe formunun kabul edilir, geçerli ve güvenilir bir anket olduğu sonucuna varıldı.

Anahtar Kelimeler: Yaşam kalitesi; görme özürlü

Turkiye Klinikleri J Med Sci 2010;30(1):207-12

- he World Health Organization estimated in 2002 that 37 million people around the world were blind and an additional 124 million had low vision. ${ }^{1}$ Blindness and severe visual impairment have a significant impact on the socioeconomic development of individuals and societies. So, preventive, curative and rehabilitative programs should be available and accessible for all blind and visually-impaired people. 
To facilitate the resource allocation decisions both at the level of clinical and health care policy, different health care programs and technologies should be assessed not only in terms of effectiveness, but also in terms of efficiency (cost-effectiveness/utility). Both direct and indirect or multiattribute methods can be used to compare the efficiency of different health care programs. ${ }^{2}$ One of the indirect methods for measuring the effectiveness of health care programs in their economic evaluation is $15 \mathrm{D}$. The $15 \mathrm{D}$ is available in many languages and its use and qualities are described for a growing number of different populations and settings.

To our knowledge, the Turkish version of the $15 \mathrm{D}$ has not been used in studies in visually-impaired populations, therefore, little is known about its acceptability, validity and reliability in this population group. This study aims to establish the validity and reliability of the Turkish version of the $15 \mathrm{D}$ in a population of visually-impaired subjects.

\section{MATERIAL AND METHODS}

\section{SUBJECTS}

This prospective observational study investigated the psychometric properties of the Turkish version of the generic 15D instrument. The study was conducted in Ankara, Turkey between March and April 2008. Sample size was determined based on detecting a correlation coefficient of at least 0.40 between the null hypothesis correlation and alternative hypothesis correlation. A sample size of 46 achieves $80 \%$ power to detect a difference of -0.40 between the null hypothesis correlation of ' 0 ' and the alternative hypothesis correlation of 0.40 using a 2-sided hypothesis test with a significance level of 0.05 . To compensate for an assumed non-participation rate of approximately $20 \%$, the sample size was increased to 57.

Fifty-seven visually-impaired subjects who have a visual acuity of less than $6 / 60$ Snellen were randomly selected from the members of an association of blind people. Those who were less than 18 years of age and the ones with a chronic disease were not included in the study. Sighted people we- re selected consecutively from those who accompanied their relatives or friends for outpatient treatment in our department. Those who were suffering from a chronic disease were not included in the study. Each participant was informed about the study and they gave their written informed consent to participate. The ethical committee approval was obtained from Hacettepe University Ethical Committee.

\section{INSTRUMENTS}

This study was conducted by interview and consisted of four main elements: A background questionnaire, an individual material wealth assessment, a health-related quality of life (HRQoL) assessment, and a depression assessment. The background questionnaire collected information on the socio-demographic and clinical characteristics of the respondents. Respondents who completed the background questionnaire were then asked to complete the Family Affluence Scale (FAS), 15D questionnaire and the Beck Depression Inventory (BDI).

The HRQoL of the subjects were assessed using the $15 \mathrm{D}$ questionnaire. The $15 \mathrm{D}$ is a generic self-administered instrument of HRQoL that can be used both as a profile and as a single index score measure. It covers the physical, psychological and social aspects of health as defined by the World Health Organization. It describes the health status, assessing 15 dimensions, namely: mobility, vision, hearing, breathing, sleeping, eating, speech, elimination, usual activities, mental function, discomfort and symptoms, depression, distress, vitality, and sexual activity. Each dimension comprises one question with five levels. For each dimension, the respondent must choose one of the five levels that best describes his/her state of health at the moment (best level=1; worst level=5). A single index score is obtained by population based preference weights to the dimensions. Index score ranges from 1 (no problems on any dimension) to zero (being dead). The original Finnish 15D instrument has shown good test-retest reliability, construct validity, and discriminatory power in general populations..$^{3-5}$ The Turkish version of the $15 \mathrm{D}$ has proved to be valid and reliable in patients with Type 2 diabetes. ${ }^{6}$ 
The depression level of subjects was described using the BDI. The BDI is a 21-item self-report instrument intended to assess the existence and severity of symptoms of depression. ${ }^{7}$ Each of the 21-items of the BDI examines somatic, affective, and cognitive symptoms of depression. Each item is a list of four statements arranged in increasing severity about a particular symptom of depression. Numerical values of zero, one, two, or three are assigned each statement to indicate degree of severity. Subjects select the item within each group that best describes how they felt during the past week. Inventory scores range from 0 to 63 , with higher scores being a sign of more severe depression. The Turkish version of the BDI has been shown to be valid and reliable. ${ }^{8}$ Individual material wealth of the respondents was measured using the FAS. ${ }^{9}$ The FAS was composed of four items: does your family own a car (0, 1, 2 or more); do you have your own bedroom for yourself? $(0,1)$; how many times did you travel away on holiday with your family during the past 12 months? (0, 1, 2, 3 or more); and how many computers does your family own $(0,1$, 2,3 or more). The criteria were adjusted for general population because this scale was developed with adolescents. A reliability analysis showed that the second question (Do you have your own bedroom for yourself?) had a zero variance. The second item was therefore was removed from the scale. The remaining three items had a Cronbach's alpha coefficient of 0.70 , which is within the conventional range of $0.70-0.90 .^{10,11}$ A principal component analysis revealed that these three items loaded significantly on a single factor with an Eigenvalue of 1.88 . This factor accounted $62.7 \%$ of the variation. After this analysis, a composite FAS score was calculated by summing the responses to three items ranging from 0 to 8 .

\section{PROCEDURE}

Study instruments were administered by the first (MKG) and third author (EHT) to the study subjects. Visually-impaired subjects who had participated in the first phase of the study (Time 1) were interviewed one week later (Time 2) by the same author (MKG). To derive the 15D score, there must be a response to each question. So, we defined missing data for each question of the 15D prior to further analysis. We dealt with missing data problem using regression analysis. ${ }^{4}$ In order to do this, we first defined the dimension with missing data as a dependent variable in regression analysis. Then, we performed regression analysis with age, gender, education level, and composite FAS score as independent variables. Missing data was replaced with the predicted mean value of the dependent variable. In this procedure, we kept the coding of the variable original, i.e., $1-5 .{ }^{12}$

\section{ANALYSIS}

The Statistical Package for the Social Sciences (SPSS for Windows 13.0) was used to perform data analyses. Analysis of the data involved both descriptive and inferential statistics including means, standard deviations (SD), standard errors (SE), and correlation coefficients. To remove the effects of co-variants, which can modify the relationship of the categorical independents to the interval dependent ANCOVA test was used. The significance level for statistical analyses was set at $\mathrm{p}<0.05$ (2-tailed).

To evaluate the association between the 15D index score and the respondent characteristics, correlation coefficients were calculated. Pearson's correlation coefficients ( $r$ ) were used to assess the linear association between scores on the index score of 15D and a number of continuous variables (age, highest year of education completed, composite FAS score). Point- bi-serial correlation coefficients $\left(\mathrm{p}_{\mathrm{bc}}\right)$ were calculated manually to determine if there was a relationship between the index score of $15 \mathrm{D}$ and the dichotomous variables [gender $(0=$ male, $1=\mathrm{fe}-$ male), marital status ( $0=$ married, $1=$ single), having an additional health problem $(0=$ no, $1=$ yes $)$ ] Correlation coefficients were interpreted as follows: very weak $=0.00$ to 0.19 ; weak $=0.20$ to 0.39 ; moderate $=$ 0.40 to 0.59 ; strong $=0.60$ to 0.79 ; very strong $=0.80$ to $1.00 .{ }^{13}$ Acceptability was assessed in terms of refusal rate and rates of missing data.

Internal consistency reliability of the 15D instrument was assessed by Cronbach's alpha coefficient at Time 1 and Time 2. An alpha value of 0.70 
or higher was considered as the acceptable reliability for group comparisons. ${ }^{10,11}$ Test-retest reliability of the index scores was assessed by intraclass correlation coefficient (ICC). ICC was interpreted as follows: poor reproducibility $=\mathrm{p}<04$; fair to good reproducibility $=0.4 \leq \mathrm{p}<0.75$; excellent $=\mathrm{p} \geq$ $0.75 .{ }^{14}$

To determine the concurrent-criterion validity of the 15D instrument, we used "known group technique"15 with the following hypotheses: 1) respondents who have a score above 17 on the BDI tend to have a lower mean 15D index score than those who have a score below of 17 on the BDI; ${ }^{7} 2$ ) respondents who have an additional chronic health problem tend to have a lower mean 15D index score than those without an additional chronic health problem; 3) visually-impaired subjects tend to have a lower mean $15 \mathrm{D}$ index score than the sighted subjects. Content validity was assessed by examining the floor and ceiling effects in the 15D index score. ${ }^{16-19}$ We hypothesized that floor and ceiling effects were less than $20 \%{ }^{20}$

\section{RESULTS}

As shown in Table 1, the study groups were balanced in terms of gender. The mean age of visuallyimpaired subjects was $36.6( \pm 12.3 \mathrm{SD})$, while that of sighted subjects was 54.4 ( $\pm 11.6 \mathrm{SD})(\mathrm{p}<0.05)$. Most of the visually-impaired subjects were single
(64.9\%), with a mean education level of $8.8( \pm 4.6$ $\mathrm{SD})$ years and with a mean FAS score of $1.8( \pm 1.4$ SD). The study groups were significantly different from each other in terms of marital status, education level, individual material wealth, and the BDI score (all p's< 0.05).

As shown in Table 2, among socio-demographic variables studied, the age $(r=-0.41 ; 95 \%$ CI:0.61 to $-0.17 ; \mathrm{p}<0.05$ ), having an additional chronic health problem ( $r=-0.46$; 95\% CI:- 0.64 to $0.23)$ and BDI score ( $r=-0.63$; 95\% CI:- 0.61 to 0.17 ; $<<0.05$ ) were significantly correlated with 15 D Score. Twelve (21.2\%) of the visually-impaired subjects had an additional chronic health problem.

\section{ACCEPTABILITY}

Five $(8.7 \%)$ visually-impaired subjects refused to take part in the second interview without giving a reason. There were no significant differences between refusers and participants in terms of age, gender, marital status, educational level, individual material wealth, and depression level (all p's< 0.05). In Time 1, the percentage of missing data across the 15 dimensions ranged from no missing data to a high of $5.3 \%$ (dimension \#3).

\section{RELIABILITY}

Reliability was assessed for subjects who participated both in the first and second interview $(\mathrm{N}=52)$.

\begin{tabular}{|c|c|c|c|}
\hline \multirow[b]{2}{*}{ Characteristics } & \multicolumn{2}{|c|}{ Groups } & \multirow[b]{2}{*}{$\mathrm{p}$ value } \\
\hline & Visually-impaired $(\mathrm{N}=57)$ & Sighted $(N=63)$ & \\
\hline Gender (male), $n(\%)$ & $39(68.4)$ & $34(54.0)$ & $0.105^{\dagger}$ \\
\hline Age, mean (SD), years & $36.6(12.3)$ & $54.4(11.6)$ & $0.001^{\ddagger}$ \\
\hline \multicolumn{4}{|l|}{ Marital status, $n(\%)$} \\
\hline Married & $20(35.1)$ & $51(81.0)$ & \multirow[t]{2}{*}{$0.001^{\dagger}$} \\
\hline Single & $37(64.9)$ & $12(19.0)$ & \\
\hline Highest year of education completed, mean (SD) & $8.8(4.6)$ & $11.2(3.7)$ & $0.005^{\ddagger}$ \\
\hline Composite FAS score, mean (SD) & $1.8(1.4)$ & $3.4(1.9)$ & $0.001^{\ddagger}$ \\
\hline \multicolumn{4}{|l|}{ Having an additional chronic health problem, $n(\%)$} \\
\hline Yes & $12(21.2)$ & \multirow[t]{2}{*}{-} & \multirow[t]{2}{*}{ NA } \\
\hline No & $45(78.9)$ & & \\
\hline BDI score, mean (SD) & $7.9(8.5)$ & $4.4(5.5)$ & $0.016^{\ddagger}$ \\
\hline
\end{tabular}

FAS: Family Affluence Scale; t: Chi-square test; $:$ : Mann-Whitney test. BDI: Beck depression Inventory. 
TABLE 2: Correlation coefficients between the Turkish version of the $15 \mathrm{D}$ index score and the characteristics of participants in visually-impaired group (Time 1) $(\mathrm{N}=57)$

\begin{tabular}{|lcc|}
\hline & Correlation coefficients & P value \\
Age & $r=-0.41$ & 0.001 \\
Highest year of education completed & $r=0.22$ & 0.093 \\
Composite FAS score & $r=0.16$ & 0.250 \\
Gender & $p_{b c}=-0.18$ & 0.092 \\
Marital status & $\mathrm{p}_{b c}=0.03$ & 0.856 \\
Having an additional chronic health problem & $\mathrm{p}_{b c}=-0.46$ & 0.001 \\
BDI score & $r=-0.63$ & 0.001 \\
\hline
\end{tabular}

Gender ( $0=$ male, $1=$ female), marital status $(0=$ married, $1=$ single), having an additional chronic health problem $(0=$ no, $1=y e s)$

$r=$ Pearson's correlation coefficient; $p b c=$ Point-biserial correlation coefficient.

FAS: Family affluence skale.

BID: Beck depression inventory.

Cronbach's alpha for the $15 \mathrm{D}$ index was 0.75 at Time 1 and 0.78 at Time 2, which was obtained after removal of two dimensions (dimensions \# 6 and 7) from the index because of zero variance. ICC for the $15 \mathrm{D}$ index was 0.95 .

\section{CONCURRENT-CRITERION AND CONTENT VALIDITY}

Table 3 shows the results of the concurrent-criterion validity analyses. As we hypothesized, after controlling for the influence of age, subjects who had a score above of 17 on the BDI had a lower mean 15D index score than those who had a score below of 17 ( $p<0.05)$. Subjects who had an additional chronic health problem had a lower mean 15D index score than those without an additional chronic health problem $(\mathrm{p}<0.05)$. Visually-impaired subjects' index score on the 15D was significantly lower than those of sighted subjects $(\mathrm{p}<$
0.05). There were no ceiling or floor effects in the $15 \mathrm{D}$ index score

\section{DISCUSSION}

In the present study we assessed the Turkish version of the generic 15D instrument's acceptability, validity and reliability in visually-impaired people. The response rate for Time 1 was 100\%, for Time 2, $91.3 \%$. With regard to missing data, $5 \%$ to $10 \%$ missing data per variable are not considered large. ${ }^{21}$ Our results indicated that the percentage of missing data was less than $10 \%$ for each of the dimensions. This result is consistent with a previous research that reported the completion rate by dimensions were $96-99 \% .{ }^{22}$ The lower completion rate for the dimension of hearing in the present study may indicate that this dimension is slightly less acceptable than the others in this population group. The high response and completion rates show that the Turkish version of the generic 15D instrument is acceptable for visually-impaired people.

Internal consistency reliability in the present study was lower than previously reported for the 15D instrument. ${ }^{6}$ However, we found that Cronbach's alpha values for the Turkish version of the $15 \mathrm{D}$ instrument exceed the suggested cutoff value of 0.70 , revealing an acceptable level of reliability for group comparisons. ${ }^{10,11}$ Test-retest reliability in the present study was excellent. This finding is consistent with a previous study. ${ }^{6}$ The results of reliability analyses of the 15D suggest that the Turkish version of the generic $15 \mathrm{D}$ instrument is a reliable instrument for assessing the health state of visually-impaired people.

\begin{tabular}{|lcccc|}
\hline \multicolumn{5}{c}{ TABLE 3: Concurrent-criterion validity of the Turkish version of the generic 15D instrument. } \\
\hline \multirow{3}{*}{ BDI score } & Criteria & N & 15D index score, mean (SE) & P values $^{*}$ \\
& $\leq 17$ & 43 & $0.9209(0.006) \dagger$ & 0.005 \\
Having an additional chronic health problem & $\geq 18$ & 9 & $0.8754(0.014) \dagger$ & 0.002 \\
& No & 41 & $0.9233(0.007) \ddagger$ & $0.8746(0.013) \ddagger$ \\
Groups & Ses & 11 & $0.9383(0.008) \ddagger$ & 0.017 \\
& Vishted & 63 & $0.9069(0.009) \ddagger$ & \\
\hline
\end{tabular}

*: P values obtained from ANCOVA test

$\dagger$ : Estimated means after controlling of age and having an additional chronic illness

$\ddagger$ : Estimated means after controlling of age and the BDI score.

BDI: Beck depression Inventory. 
Concurrent-criterion validity demonstrated that the Turkish version of the generic $15 \mathrm{D}$ was able to differentiate between groups with known differences in clinical problems. Floor effects are seen when subject scores are grouped at fair/poor state of health. Ceiling effects are seen when subject scores are grouped at excellent/very good state of health. In the present study, there were no ceiling or floor effects in the 15D index score. The absence of ceiling or floor effects indicates that the Turkish version of the generic $15 \mathrm{D}$ instrument is able to distinguish between subjects with different levels of health state. ${ }^{23}$

Several possible limitations should be considered when interpreting the results of this study. The results reported here do not provide evidence on responsiveness and feasibility of the 15D instrument. Further longitudinal studies evaluating the responsiveness and feasibility are needed. In addition, data were mainly collected from the members of an association of blind people in Ankara, and therefore cannot be generalized to all blind people in Turkey. However, in the light of the results presented in this study, we concluded that the Turkish version of the generic 15D instrument was an acceptable, valid and reliable measure of HRQoL for people with visual-impairment.

\section{Acknowledgement}

The authors thank Prof. Harri Sintonen for his kind permission to use the Turkish version of the generic $15 D$ instrument.

\section{REFERENCES}

1. Taylor HR, Pezzullo ML, Nesbitt SJ, Keeffe JE. Costs of interventions for visual impairment. Am J Ophthalmol 2007;143(4):561-5.

2. Kymes SM, Lee BS. Preference-based quality of life measures in people with visual impairment. Optom Vis Sci 2007;84(8):809-16.

3. Sintonen, $\mathrm{H}$. The $15 \mathrm{D}$ instrument of healthrelated quality of life: properties and applications. Ann Med 2001;33(5):328-36.

4. Sintonen $\mathrm{H}$, Pekurinen M. A fifteen dimensional measure of health-related quality of life (15D) and its applications. In: Walker SR, Rosser RM, eds. Quality of life assessment, $1^{\text {st }}$ ed. Dordrecht, the Netherlands: Kluwer; 1993. p.185-470.

5. Sintonen $\mathrm{H}$, Pekurinen M. A generic $15 \mathrm{di}-$ mensional measure of health-related quality of life (15D). J Soc Med 1989; 26 (1): 85-96.

6. Akinci F, Yildirim A, Ogutman B, Ates M, Gozu $\mathrm{H}$, Deyneli O, et al. Translation, cultural adaptation, initial reliability, and validation of Turkish 15D's version: a generic health-related quality of life (HRQoL) instrument. Eval Health Prof 2005;28(1):53-66.

7. Beck AT, Ward CH, Mendelson M, Mock J, Erbaugh J. An inventory for measuring depression. Arch Gen Psychiatry 1961;4:561-71.

8. Hisli N. [A study on the validity of Beck Depression Inventory]. Turk J Psychol 1988;6(2):118-22.
9. Boyce W, Torsheim T, Currie C, Zambon A. The family affluence scale as a measure of national wealth: Validation of an adolescent selfreport measure. Soc Indic Res 2006;78(3): 473-87.

10. Lemond LC, Durham RL, Slater GP, Wilson WH, Nunnally JC. Varying degrees of complexity and isolation in visual exploration. Percept Mot Skills 1974;38(3):787-94.

11. DeVellis RF. Classical test theory. Med Care 2006;44(11 Suppl 3):S50-9.

12. Brommels $M$, Sintonen $H$. Be generic and specific: quality of life measurement in clinical studies. Ann Med 2001;33(5):319-22.

13. Swinscow TD. Statistics at square one. XXCorrelation (concluded). Br Med J 1976; 2(6039):802-3

14. Rosner B, Willett WC. Interval estimates for correlation coefficients corrected for withinperson variation: implications for study design and hypothesis testing. Am J Epidemiol 1988;127(2):377-86.

15. Helmstadter GC. Principles of Psychological Measurements. $1^{\text {st }}$ ed. New York: AppletonCentury-Crofts Inc; 1964. p.122-89.

16. Leigh Brown AP, Kennedy ADM, Grant AM, Campbell J, Macnicol MF, Torgerson DJ. The development and validation of the Edinburgh Knee Function Scale: a simple tool for outcome measurement in non-surgical patients. Knee 1999;6(2):115-23.
17. Roos EM, Roos HP, Ekdahl C, Lohmander LS. Knee injury and Osteoarthritis Outcome Score (KOOS)--validation of a Swedish version. Scand J Med Sci Sports 1998;8(6):43948.

18. Dunbar MJ, Robertsson O, Ryd L, Lidgren L. Translation and validation of the Oxford-12 item knee score for use in Sweden. Acta Orthop Scand 2000;71(3):268-74.

19. Dunbar MJ, Robertsson O, Ryd L, Lidgren L. Appropriate questionnaires for knee arthroplasty. Results of a survey of 3600 patients from The Swedish Knee Arthroplasty Registry J Bone Joint Surg Br 2001;83(3):339-44 .

20. McHorney CA, Tarlov AR. Individual-patient monitoring in clinical practice: are available health status surveys adequate? Qual Life Res 1995;4(4):293-307.

21. Cohen J, Cohen, P. Applied Multiple Regression/Correlation for the Behavioral Sciences. $2^{\text {nd }}$ ed. Hillsdale, NJ: Erlbaum; 1983. p. 490598.

22. Sintonen $\mathrm{H}$. Comparing properties of the $15 \mathrm{D}$ and the EQ-5D in measuring health-related quality of life. Arch Hell Med 2001;18(2):15660.

23. Stucki G, Liang MH, Fossel AH, Katz JN. Relative responsiveness of condition-specific and generic health status measures in degenerative lumbar spinal stenosis. J Clin Epidemiol 1995;48(11):1369-78 